\title{
The Homophilic Domain - An Immunological Archetype
}

\author{
Heinz Kohler ${ }^{1 *}$, Jagadeesh Bayry ${ }^{2,3,4,5}$ and Srinivas V. Kaveri ${ }^{2,3,4,5 *}$ \\ ${ }^{1}$ Department of Microbiology Immunology, University of Kentucky, Lexington, KY, USA, ${ }^{2}$ Institut National de la Santé et de la \\ Recherche Médicale Unité 1138, Paris, France, ${ }^{3}$ Centre de Recherche des Cordeliers, Equipe - Immunopathologie et \\ immuno-intervention thérapeutique, Paris, France, ${ }^{4}$ Sorbonne Universités, UPMC Univ Paris 06, UMR S 1138, Paris, France, \\ ${ }^{5}$ Université Paris Descartes, Sorbonne Paris Cité, UMR S 1138, Paris, France
}

The homophilic potential emerges as an important biological principle to boost the potency of immunoglobulins. Since homophilic antibodies in human and mouse sera exist prior environmental exposure, they are part of the natural antibody repertoire. Nevertheless, hemophilic properties are also identified in induced antibody repertoire. The use of homophilicity of antibodies in the adaptive immunity signifies an archetypic antibody structure. The unique feature of homophilicity in the antibody repertoire also highlights an important mechanism to boost the antibody potency to protect against infection and atherosclerosis as well to treat cancer patients.

Ana María Hernández,

Center of Molecular Immunology,

Cuba

Reviewed by:

Mepur Hanumantha-Rao Ravindranath

Terasaki Foundation Laboratory, USA Ronald B. Corley,

Boston University School of Medicine, USA

${ }^{*}$ Correspondence: Heinz Kohler

heinz.kohler@uky.edu;

Srinivas V. Kaver srini.kaveri@crc.jussieu.fr

Specialty section:

This article was submitted to B Cell Biology, a section of the journal

Frontiers in Immunology

Received: 08 February 2016 Accepted: 07 March 2016

Published: 21 March 2016

Citation:

Kohler H, Bayry J and Kaveri SV (2016) The Homophilic Domain - An Immunological Archetype. Front. Immunol. 7:106. doi: 10.3389/fimmu.2016.00106
Keywords: natural antibodies, homophilic, immunoglobulins, idiotype, induced antibodies, T15, 1F7

\section{NATURAL ANTIBODIES - THE VIRGIN IMMUNE RESPONSE}

Natural antibodies are immunoglobulins in sera of mammalians that are neither immunologically challenged nor responding. For example, natural antibodies are in sera of neonatal or germ-free mice. Natural antibodies are of $\operatorname{IgM}, \operatorname{IgG}$, and IgA isotypes and play an important role in the immune homeostasis and protection against pathogens (1-6). B1 cells in mice produce natural antibodies $(7,8)$. In human, $\mathrm{CD} 20^{+} \mathrm{CD} 27^{+} \mathrm{CD} 43^{+}$memory $\mathrm{B}$ cells were recently identified as murine $\mathrm{B} 1$ counterpart (9). Natural antibodies are the important components of the therapeutic intravenous immunoglobulin (IVIG) (10-12) that is widely used in the therapy of autoimmune and inflammatory diseases (13-17). These functions of natural antibodies also indicate diverse roles played by B cells in the immune homeostasis (18-22).

\section{THE IDIOTYPIC INTERACTIONS}

Oudin and Jerne are the founders of the idiotype concept $(23,24)$. They "discovered" that one antibody could recognize another antibody as an individual and unique member of the immune system. The uniqueness of an antibody lies in the variable region of heavy and light chains and has been named idiotype. The idiotype antibody individuality is separated from the antigen-binding site, also determined by unique sequence variability. However, both regions are linked by a unique variability and have a functional relation. Identifying an antigen-binding site also reveals the linked idiotype and vice versa, an idiotope reveals the associated antigen specificity. However, there are important exceptions to this linkage rule: the so-called common idiotopes (IdX) are expressed on antibodies with different antigen specificities (25). Furthermore, antigen-binding site and idiotype site can be identical or overlapping. 
Studies on the functional interactions of anti-idiotype binding to antibodies have established a classification in the idiotype field. Jerne termed anti-idiotypes that do not interfere with the antigen-binding site as $\mathrm{Ab} 2 \alpha$ and anti-idiotypes that block the antigen binding as $\mathrm{Ab} 2 \beta$ (26). Ab2 was further differentiated by adding the term $A b 2 \gamma$ to describe $A b 2$ that only partially inhibits antigen binding $(27,28)$. The Ab2 $\beta$ has another unique functional feature. It mimics the antigen by its perfect fit into another antigen-binding site. Ab2 $\beta$ has been used as antigen to induce a specific immune response (28). Another shared idiotype has been discovered in HIV-infected primates (29). This anti-idiotype antibody has been termed as Ab2 $\delta$ (30).

In mice, "prime" antibodies lack the dominant expression of certain shared idiotype, such as the so-called T15 idiotype, that develops weeks after birth without environmental challenge (31, 32). Therefore, the T15 dominance can be considered a part of the natural antibody repertoire. The T15 idiotype is also present in primates, including man (33). Perhaps a review of the idiotypic circuits is helpful for the understanding of the biological and immunological properties of the T15 archetypic idiotype. A hallmark of the T15 antibody family is their ability to self bind for producing homophilic complexes (34-36). The domain responsible for antibody self-binding (homophilicity) has been described as a region in $\mathrm{VH}$ of $\mathrm{T} 15$, extending from CDR2 to Fr3 $(35,37)$. Because of their preimmune presence in normal sera, homophilic antibodies are segment of the natural antibody repertoire $(33,37)$.

\section{THE BIOLOGY AND IMMUNOREGULATORY FUNCTIONS OF HOMOPHILIC ANTIBODIES}

The homophilic domain in antibodies was identified, and peptides that can confer the homophilic effect to other antibodies were made (38). Further studies showed that the homophilic domain can be expressed independently from the specificity of the antigen-binding site (39). This suggested that any antibody could be made homophilic by attaching the homophilic domain. In early experiments, a chemical affinity conjugation method was introduced to make the homophilic Ig (40); later, recombinant techniques were used to produce a homophilic antibody fusion protein.

Human and mouse sera contain antibodies that express the homophilic domain (33), confirming that homophilic antibodies are part of the so-called natural antibodies (41). Homophilic antibodies with specificity for phosphorylcholine (PC) are superior in protecting against Streptococcus pneumoniae infection (42). Homophilic anti-PC antibodies are also highly effective to reduce atherosclerotic plaque formation $(43,44)$ and perhaps have other housekeeping functions. Antigenicity of the homophilic domain was tested in mice, rabbits, and non-human primates by injecting the homophilic domain peptide and treating macaques with a homophilic anti-CD20 antibody (45). No antibodies could be detected against the homophilic domain. This finding suggests that homophilic antibodies could be used as therapeutic drugs to treat human diseases without allergic side effects (46).
Indeed, human natural antibodies with specificity for PC protect against atherosclerotic plaque formation by binding to oxidized LDL and inhibit macrophage activation $(43,47)$. Immunizing atherosclerotic mice with $\mathrm{PC}$ antigen reduces plaque formation (44). Silverman and colleagues showed that SLE patients with low natural antibodies develop more serious disease (48). Emerging evidence suggested that natural antibodies could control transplant rejection (49).

Another "natural" antibody in normal human sera has been described with specificity for HLA (50). This anti-HLA is not detectable in sera but is revealed after IgG purification. The homophilic T15 peptide from the complementarity-determining region/framework masked the HLA recognition of non-purified IgG. Since the T15 homophilic peptide dissociate the homophilic Ig complex, thereby reducing the polyvalency and binding potency, one can conclude that in sera, auto-anti-HLA antibodies are bound to corresponding HLA and are not detected. It follows that natural auto-anti-HLA antibodies are homophilic. Thus, the homophilic property of antibodies plays a role in the functional regulation of antibodies either by masking them or by exposing them under appropriate conditions.

A homophilic state of the Ig B-cell receptor (BCR) has been described in chronic lymphocytic leukemia $(51,52)$. Peptides from the VH Ig BCR bind to the BCR providing the basis for selfrecognition of the BCR. Recently, we used the T15 homophilic peptide to inhibit proliferation of murine human B-cell lines (46).

\section{THE UNIQUE BIOPHYSICAL PROPERTIES OF HOMOPHILIC ANTIBODIES}

Working with homophilic-converted Trastuzumab (Herceptin), we discovered that the dose-response in inducing apoptosis in a Her2/neu-expressing human cell line was not linear but was bell shaped (53). The highest concentration tested did not induce the highest amount of apoptosis, but a lower concentration produced the most apoptosis. Similar non-linear dose effects were observed in fluorescence staining of tumor cells. This paradoxical dose effect was also observed in xenograft experiment (54).

This non-linear dose affecting the potency of homophilic Herceptin could be due to the inherent mechanic of self-binding that was observed in $1986(37,55)$. Here, self-binding of the T15 antibody decreases as the concentration of homophilic antibody increases, producing a bell-shaped pattern. This indicates that the equilibrium of self-bound antibody and free antibody is controlled by the concentration of homophilic antibody. Thus, the lattice of build up of homophilic antibodies at the tumor target cell would decrease at a higher concentration, thereby reducing apoptosis. This paradoxical effect has been observed with homophilic antiHer2/neu (Herceptin) (54). In this study, we showed that the viscosity of homophilic antibodies increases with temperature and decreases at lower temperature, an effect not observed with the most other proteins or organic compounds. Furthermore, the binding to antigen by a homophilic antibody is also higher at physiological temperature than by the non-homophilic parental antibody. Lastly, the binding of homophilic Herceptin to tumor cells is concentration dependent, whereby a lower concentration 
targets better than a higher concentration. The unique biophysical properties of homophilic antibodies represent another aspect in the natural antibody repertoire.

\section{HOMOPHILICITY IN SHARED IDIOTYPES}

We believe that we are only at the beginning to discover networks of shared idiotypes. By using polyclonal anti-idiotype antibodies, Urbain and colleagues have observed shared idiotypes expressed on antibodies with different antigen specificity in rabbits and mice $(26,56)$. The monoclonal 1F7 anti-idiotype recognizes antibodies against viral antigens and is first described in humans $(29,57,58)$. The T15 and 1F7 idiotypic networks harbor important biological and medical properties: dominant T15 antibodies protect against pneumococcal infection (59) and perform a housekeeping function to reduce atherosclerotic plaque formation (43); the 1F7 idiotope is expressed on antibodies against $\operatorname{HIV}-1(57,60)$ and hepatitis $\mathrm{C}(61,62)$ (see also contribution by Muller et al.). Furthermore, 1F7-positive human anti-HIV-1 antibodies carry the homophilic domain (Veljkovic and Kohler, unpublished). These studies on homophilic antibodies show that homophilicity is utilized in the innate immunity (natural antibodies) and by the adaptive immune response.

\section{HOMOPHILICITY AS A GENERAL CONCEPT IN SYSTEM BIOLOGY OF NATURAL ANTIBODIES}

The data on homophilic natural antibodies point to a general strategy of enhancing potency not only of antibodies but also other biological systems (63). This finding can be viewed as a paradigm in System Biology in the T15 and 1F7 idiotypic networks. Both systems utilize the antibody homophilicity. Both systems also use this property to achieve a high level of antibody potency. Antibodies with T15 expression in normal sera are close to germline encoding: (i) the T15 dominance develops late in ontogeny (31), (ii) the homophilic domain contains $\mathrm{H} 2$ mutations, (iii) analysis of the neonatal repertoire by Coutinho (64) shows only evidence for extensive idiotypic network and for homophilic binding, and (iv) homophilic antibodies have been detected after stimulation $(38,46)$. Furthermore, in support of the adaptive creation of the homophilic domain, the sequence

\section{REFERENCES}

1. Avrameas S. Natural autoantibodies: from 'horror autotoxicus' to 'gnothi seauton'. Immunol Today (1991) 12(5):154-9. doi:10.1016/S0167-5699(05)80045-3

2. Kohler H, Bayry J, Nicoletti A, Kaveri SV. Natural autoantibodies as tools to predict the outcome of immune response? Scand Jimmunol (2003) 58(3):285-9. doi:10.1046/j.1365-3083.2003.01314.x

3. Elluru SR, Vani J, Delignat S, Bloch MF, Lacroix-Desmazes S, Kazatchkine $\mathrm{MD}$, et al. Modulation of human dendritic cell maturation and function by natural IgG antibodies. Autoimmun Rev (2008) 7(6):487-90. doi:10.1016/j. autrev.2008.04.014

4. Kaveri SV, Silverman GJ, Bayry J. Natural IgM in immune equilibrium and harnessing their therapeutic potential. J Immunol (2012) 188(3):939-45. doi:10.4049/jimmunol.1102107 of homophilic domains is found different $(51,52)$. Thus, certain homophilic antibodies are not part of the so-called natural antibodies but are induced by antigenic stimulation.

The homophilic antibody enhancement and therapeutic potential have been already demonstrated $(38,46)$. The native dominant expression of 1F7 idiotype on anti-HIV-1 antibodies may lead to a novel vaccine concept (65). There is one important difference between the T15 and the 1F7 system: T15 antibodies are present in preimmune serum without external antigen exposure; 1F7 antibodies recognizing anti-HIV and anti-HBC antibodies are induced after infection and are not natural antibodies. Nemazee et al. recently promoted the idea of targeting germline antibodies for inducing a maturation sequence, leading to broadly neutralizing Abs against HIV-1 (66). The use of a germline targeting immunogen is different from the concept of stimulating B-cells with idiotype expressing receptors. Prior to triggering, these B-cells do not produce detectable antibodies and do not contribute to the natural antibody repertoire (57). Using the 1F7 antibody as vaccine would not require additional immunogen(s) to trigger the antibody maturations process, since the 1F7 idiotype is expressed by potent broadly neutralizing Abs (Parsons, unpublished). HIV-1 infection is expected to stimulate the expanded clones of 1F7 expressing B-cells to produce broadly neutralizing Abs (57).

\section{SUMMARY}

The discussion of the unique feature of homophilicity as a part of the natural and induced antibody repertoires (65) highlights an important mechanism to boost the antibody potency to protect against infection and atherosclerosis (44) as well to treat cancer patients (46). The concept of homophilicity is introduced here to describe the unique coexistence and synergism of acquired immunity with innate immunity. The homophilicity of antibodies in the natural and acquired repertoires emerges as an archetypic principle in the immune system.

\section{AUTHOR CONTRIBUTIONS}

HK surveyed the literature and wrote the article. JB and SK provided suggestions. All authors approved the final version of this article for publication and accepted the responsibility for the integrity of the work.

5. Elluru SR, Kaveri SV, Bayry J. The protective role of immunoglobulins in fungal infections and inflammation. Semin Immunopathol (2015) 37(2):187-97. doi:10.1007/s00281-014-0466-0

6. Cunningham AF, Flores-Langarica A, Bobat S, Dominguez Medina CC, Cook CN, Ross EA, et al. B1b cells recognize protective antigens after natural infection and vaccination. Front Immunol (2014) 5:535. doi:10.3389/ fimmu.2014.00535

7. Sidman CL, Shultz LD, Hardy RR, Hayakawa K, Herzenberg LA. Production of immunoglobulin isotypes by Ly-1+ B cells in viable motheaten and normal mice. Science (1986) 232(4756):1423-5. doi:10.1126/ science. 3487115

8. Baumgarth N. The double life of a B-1 cell: self-reactivity selects for protective effector functions. Nat Rev Immunol (2011) 11(1):34-46. doi:10.1038/ nri2901 
9. Griffin DO, Holodick NE, Rothstein TL. Human B1 cells in umbilical cord and adult peripheral blood express the novel phenotype CD20+ CD27+ CD43+ CD70. J Exp Med (2011) 208(1):67-80. doi:10.1084/jem.20101499

10. Vani J, Elluru S, Negi VS, Lacroix-Desmazes S, Kazatchkine MD, Bayry J, et al. Role of natural antibodies in immune homeostasis: IVIg perspective. Autoimmun Rev (2008) 7(6):440-4. doi:10.1016/j.autrev.2008.04.011

11. Ravindranath MH, Terasaki PI, Pham T, Jucaud V, Kawakita S. Therapeutic preparations of IVIg contain naturally occurring anti-HLA-E antibodies that react with HLA-Ia (HLA-A/-B/-Cw) alleles. Blood (2013) 121(11):2013-28. doi:10.1182/blood-2012-08-447771

12. Bouhlal H, Martinvalet D, Teillaud JL, Fridman C, Kazatchkine MD, Bayry J, et al. Natural autoantibodies to Fcgamma receptors in intravenous immunoglobulins. JClin Immunol (2014) 34(Suppl 1):S4-11. doi:10.1007/ s10875-014-0019-2

13. Gelfand EW. Intravenous immune globulin in autoimmune and inflammatory diseases. N Engl J Med (2012) 367(21):2015-25. doi:10.1056/NEJMra1009433

14. Bayry J, Hartung HP, Kaveri SV. IVIg for relapsing-remitting multiple sclerosis: promises and uncertainties. Trends Pharmacol Sci (2015) 36(7):419-21. doi:10.1016/j.tips.2015.04.012

15. Gilardin L, Bayry J, Kaveri SV. Intravenous immunoglobulin as clinical immune-modulating therapy. CMAJ (2015) 187(4):257-64. doi:10.1503/ cmaj. 130375

16. Cantarini L, Rigante D, Vitale A, Napodano S, Sakkas LI, Bogdanos DP, et al. Intravenous immunoglobulins (IVIG) in systemic sclerosis: a challenging yet promising future. Immunol Res (2015) 61(3):326-37. doi:10.1007/ s12026-014-8615-z

17. Lunemann JD, Nimmerjahn F, Dalakas MC. Intravenous immunoglobulin in neurology - mode of action and clinical efficacy. Nat Rev Neurol (2015) 11(2):80-9. doi:10.1038/nrneurol.2014.253

18. Mauri C, Bosma A. Immune regulatory function of B cells. Annu Rev Immunol (2012) 30:221-41. doi:10.1146/annurev-immunol-020711-074934

19. Maddur MS, Kaveri SV, Bayry J. Regulation of human dendritic cells by B cells depends on the signals they receive. Blood (2012) 119(16):3863-4. doi:10.1182/blood-2012-02-408948

20. Morva A, Lemoine S, Achour A, Pers JO, Youinou P, Jamin C. Maturation and function of human dendritic cells are regulated by B lymphocytes. Blood (2012) 119(1):106-14. doi:10.1182/blood-2011-06-360768

21. Maddur MS, Sharma M, Hegde P, Stephen-Victor E, Pulendran B, Kaveri SV, et al. Human B cells induce dendritic cell maturation and favour Th2 polarization by inducing OX-40 ligand. Nat Commun (2014) 5:4092. doi:10.1038/ ncomms5092

22. Moulin V, Andris F, Thielemans K, Maliszewski C, Urbain J, Moser M. B lymphocytes regulate dendritic cell (DC) function in vivo: increased interleukin 12 production by DCs from B cell-deficient mice results in Thelper cell type 1 deviation. J Exp Med (2000) 192(4):475-82. doi:10.1084/jem.192.4.475

23. Jerne NK. Towards a network theory of the immune system. Ann Immunol (Paris) (1974) 125C:373-89.

24. Oudin J. [The idiotyping of antibodies]. Ann Immunol (Paris) (1974) 125C:309-37.

25. Cazenave PA, Oudin J. [Idiotype of antibodies, in the serum of rabbits immunized against human fibrinogen, directed against 2 different fragments of this antigen]. C R Acad Sci Hebd Seances Acad Sci D (1973) 276(2):243-5.

26. Jerne NK, Roland J, Cazenave PA. Recurrent idiotopes and internal images. EMBO J (1982) 1(2):243-7.

27. Huang JH, Ward RE, Kohler H. Idiotope antigens (Ab2 alpha and Ab2 beta) can induce in vitro B cell proliferation and antibody production. J Immunol (1986) 137(3):770-6.

28. Kohler H, McNamara M, Ward RE. Idiotypes as internal antigens. Prog Clin Biol Res (1985) 172B:343-53.

29. Muller S, Wang HT, Kaveri SV, Chattopadhyay S, Kohler H. Generation and specificity of monoclonal anti-idiotypic antibodies against human HIVspecific antibodies. I. Cross-reacting idiotopes are expressed in subpopulations of HIV-infected individuals. J Immunol (1991) 147(3):933-41.

30. Parsons MS, Muller S, Kohler H, Grant MD, Bernard NF. On the benefits of sin: can greater understanding of the 1F7-idiotypic repertoire freeze enhance HIV vaccine development? Hum Vaccin Immunother (2013) 9(7):1532-8. doi:10.4161/hv.24460

31. Fung J, Kohler H. Late clonal selection and expansion of the TEPC-15 germline specificity. J Exp Med (1980) 152(5):1262-73. doi:10.1084/jem.152.5.1262
32. Etlinger HM, Heusser $\mathrm{CH}$. T15 dominance in $\mathrm{BALB} / \mathrm{c}$ mice is not controlled by environmental factors. J Immunol (1986) 136(6):1988-91.

33. Halpern R, Kaveri SV, Kohler H. Human anti-phosphorylcholine antibodies share idiotopes and are self-binding. JClin Invest (1991) 88(2):476-82. doi:10.1172/JCI115328

34. Kaveri SV, Halpern R, Kang CY, Kohler H. Self-binding antibodies (autobodies) form specific complexes in solution. J Immunol (1990) 145(8):2533-8.

35. Kang CY, Brunck TK, Kieber-Emmons T, Blalock JE, Kohler H. Inhibition of self-binding antibodies (autobodies) by a VH-derived peptide. Science (1988) 240(4855):1034-6. doi:10.1126/science.3368787

36. Kang CY, Cheng HL, Rudikoff S, Kohler H. Idiotypic self binding of a dominant germline idiotype (T15). Autobody activity is affected by antibody valency. J Exp Med (1987) 165(5):1332-43. doi:10.1084/jem.165.5.1332

37. Kang CY, Kohler H. Immunoglobulin with complementary paratope and idiotope. J Exp Med (1986) 163(4):787-96. doi:10.1084/jem.163.4.787

38. Kohler H. Discovery of homophilic antibodies as novel drugs. Curr Trends Immunol (2009) 10:113-8.

39. Kaveri SV, Halpern R, Kang CY, Kohler H. Antibodies of different specificities are self-binding: implication for antibody diversity. Mol Immunol (1991) 28(7):773-8. doi:10.1016/0161-5890(91)90120-9

40. Russ M, Lou D, Kohler H. Photo-activated affinity-site cross-linking of antibodies using tryptophan containing peptides. J Immunol Methods (2005) 304(1-2):100-6. doi:10.1016/j.jim.2005.06.020

41. Kaveri SV, Kang CY, Kohler H. Natural mouse and human antibodies bind to a peptide derived from a germline VH chain. Evidence for evolutionary conserved self-binding locus. J Immunol (1990) 145(12):4207-13.

42. Briles DE, Forman C, Hudak S, Claflin JL. The effects of idiotype on the ability of IgG1 anti-phosphorylcholine antibodies to protect mice from fatal infection with Streptococcus pneumoniae. Eur J Immunol (1984) 14(11):1027-30. doi:10.1002/eji.1830141112

43. Shaw PX, Horkko S, Chang MK, Curtiss LK, Palinski W, Silverman GJ, et al. Natural antibodies with the T15 idiotype may act in atherosclerosis, apoptotic clearance, and protective immunity. J Clin Invest (2000) 105(12):1731-40. doi:10.1172/JCI8472

44. Caligiuri G, Khallou-Laschet J, Vandaele M, Gaston AT, Delignat S, Mandet $\mathrm{C}$, et al. Phosphorylcholine-targeting immunization reduces atherosclerosis. J Am Coll Cardiol (2007) 50(6):540-6. doi:10.1016/j.jacc.2006.11.054

45. Bingaman MG, Basu GD, Golding TC, Chong SK, Lassen AJ, Kindt TJ, et al. The autophilic anti-CD20 antibody DXL625 displays enhanced potency due to lipid raft-dependent induction of apoptosis. Anticancer Drugs (2010) 21(5):532-42. doi:10.1097/CAD.0b013e328337d485

46. Kohler H. Homophilic antibodies as immunotherapeutics. Immunotherapy (2013) 5(3):235-46. doi:10.2217/imt.12.159

47. Shaw PX, Goodyear CS, Chang MK, Witztum JL, Silverman GJ. The autoreactivity of anti-phosphorylcholine antibodies for atherosclerosis-associated neo-antigens and apoptotic cells. J Immunol (2003) 170(12):6151-7. doi:10.4049/jimmunol.170.12.6151

48. Silverman GJ. Targeting of B cells in SLE: rationale and therapeutic opportunities. Bull NYU Hosp Jt Dis (2006) 64(1-2):51-6.

49. Porcheray F, Fraser JW, Gao B, McColl A, DeVito J, Dargon I, et al. Polyreactive antibodies developing amidst humoral rejection of human kidney grafts bind apoptotic cells and activate complement. Am J Transplant (2013) 13(10):2590-600. doi:10.1111/ajt.12394

50. Ravindranath MH, Terasaki PI, Maehara CY, Jucaud V, Kawakita S, Pham T, et al. Immunoglobulin (Ig)G purified from human sera mirrors intravenous Ig human leucocyte antigen (HLA) reactivity and recognizes one's own HLA types, but may be masked by Fab complementarity-determining region peptide in the native sera. Clin Exp Immunol (2015) 179(2):309-28. doi:10.1111/cei.12450

51. Binder M, Muller F, Frick M, Wehr C, Simon F, Leistler B, et al. CLL B-cell receptors can recognize themselves: alternative epitopes and structural clues for autostimulatory mechanisms in CLL. Blood (2013) 121(1):239-41. doi:10.1182/blood-2012-09-454439

52. Duhren-von Minden M, Ubelhart R, Schneider D, Wossning T, Bach MP, Buchner M, et al. Chronic lymphocytic leukaemia is driven by antigen-independent cell-autonomous signalling. Nature (2012) 489(7415):309-12. doi:10.1038/nature11309

53. Bryan AJ, Kohler H. Physical and biological properties of homophilic therapeutic antibodies. Cancer Immunol Immunother (2011) 60(4):507-14. doi:10.1007/s00262-010-0952-8 
54. Kohler H, Bryan AJ. Paradoxical concentration effect of a homodimerizing antibody against a human non-small cell lung cancer cell line. Cancer Immunol Immunother (2009) 58(5):749-58. doi:10.1007/s00262-008-0597-Z

55. Bona CA, Kang CY, Kohler H, Monestier M. Epibody: the image of the network created by a single antibody. Immunol Rev (1986) 90:115-27. doi:10.1111/j.1600-065X.1986.tb01480.x

56. Urbain J, Tasiaux N, Leuwenkroon R, Van Acker A, Mariame B. Sharing of idiotypic specificities between different antibody populations from an individual rabbit. Eur J Immunol (1975) 5(8):570-5. doi:10.1002/ eji.1830050813

57. Wang QL, Wang HT, Blalock E, Muller S, Kohler H. Identification of an idiotypic peptide recognized by autoantibodies in human immunodeficiency virus-1-infected individuals. J Clin Invest (1995) 96(2):775-80. doi:10.1172/ JCI118122

58. Muller S, Margolin DH, Nara PL, Alvord WG, Kohler H. Stimulation of HIV1-neutralizing antibodies in simian HIV-IIIB-infected macaques. Proc Natl Acad Sci U S A (1998) 95(1):276-81. doi:10.1073/pnas.95.1.276

59. Wallick S, Claflin JL, Briles DE. Resistance to Streptococcus pneumoniae is induced by a phosphocholine-protein conjugate. JImmunol (1983) 130(6):2871-5.

60. Wang H, Muller S, Zolla-Pazner S, Kohler H. Human monoclonal and polyclonal anti-human immunodeficiency virus-1 antibodies share a common clonotypic specificity. Eur J Immunol (1992) 22(7):1749-55. doi:10.1002/ eji.1830220713

61. Grant MD. Antibody convergence along a common idiotypic axis in immunodeficiency virus and hepatitis C virus infections. J Med Virol (2002) 66(1):13-21. doi:10.1002/jmv.2105
62. Parsons MS, Rouleau D, Routy JP, LeBlanc R, Grant MD, Bernard NF. Selection of human anti-HIV broadly neutralizing antibodies occurs within the context of frozen 1F7-idiotypic repertoire. AIDS (2011) 25(10):1249-64. doi:10.1097/ QAD.0b013e328347f9fa

63. Gonen S, DiMaio F, Gonen T, Baker D. Design of ordered two-dimensional arrays mediated by noncovalent protein-protein interfaces. Science (2015) 348(6241):1365-8. doi:10.1126/science.aaa9897

64. Holmberg D, Forsgren S, Ivars F, Coutinho A. Reactions among IgM antibodies derived from normal, neonatal mice. Eur J Immunol (1984) 14(5):435-41 doi:10.1002/eji.1830140510

65. Kohler H. Novel vaccine concept based on back-boost effect in viral infection. Vaccine (2015) 33(29):3274-5. doi:10.1016/j.vaccine.2015.05.035

66. Jardine JG, Ota T, Sok D, Pauthner M, Kulp DW, Kalyuzhniy O, et al. HIV-1 Vaccines. Priming a broadly neutralizing antibody response to HIV-1 using a germline-targeting immunogen. Science (2015) 349(6244):156-61. doi:10.1126/science.aac5894

Conflict of Interest Statement: The authors declare that the research was conducted in the absence of any commercial or financial relationships that could be construed as a potential conflict of interest.

Copyright (ㄷ) 2016 Kohler, Bayry and Kaveri. This is an open-access article distributed under the terms of the Creative Commons Attribution License (CC BY). The use, distribution or reproduction in other forums is permitted, provided the original author(s) or licensor are credited and that the original publication in this journal is cited, in accordance with accepted academic practice. No use, distribution or reproduction is permitted which does not comply with these terms. 